\title{
Normative Power and the Future of EU Public Diplomacy
}

Manners, lan James; Whitman, Richard

Published in:

European Public Diplomacy

Publication date:

2013

Document version

Early version, also known as pre-print

Citation for published version (APA):

Manners, I. J., \& Whitman, R. (2013). Normative Power and the Future of EU Public Diplomacy. In M. Davis Cross, \& J. Melissen (Eds.), European Public Diplomacy: Soft Power at Work (pp. 183-204). Palgrave Macmillan. http://www.palgrave.com/products/title.aspx?pid=655222 


\title{
C H A P T E R N I N E \\ Normative Power and the Future of EU Public Diplomacy
}

\author{
IAn Manners and Richard Whitman*
}

\section{Introduction-Normative Power and Public Diplomacy}

We Europeans believe that public diplomacy plays a special role in the external relations of the European Union... Public diplomacy should reflect not only what we do or want to do; but also what we are and what we stand for. As we move towards a new and uncertain global order, this is probably more important than it has ever been. The values we considered self evident before, may not always be so in future. ${ }^{1}$

For the last two decades scholars of the European Union (EU) have been seeking to understand the EU's "international identity" in order to make sense of what the EU is and what it stands for, as much as understanding what the EU does or wants to do in global politics. ${ }^{1}$ The normative power approach to the EU in global politics has been developed specifically to understand the EU's international identity by examining its principles, actions, and impact. ${ }^{2}$ As Vicki Birchfield points out, the normative power approach represents a variation on the dialectic of being and becoming ${ }^{3}$ - that it involves both empirical analysis and "critical normative intervention. ${ }^{\text {"4 }}$

Steffen Bay Rasmussen, in line with the theme of this volume, suggests that "public diplomacy is generally associated with the notion of soft power.+.a method by which the attractiveness of a country's ideals and values can be promoted." ${ }^{n}$ But he has also made clear that the "arguments about normative power also recognise that attraction-and the corresponding diffusion of ideas and norms-does not happen automatically, [but through] specific mechanisms for normative diffusion." ${ }^{\text {"T }}$ This 
emphasis on normative power as an explicitly theoretical concept requiring an understanding of social diffusion and normative practices is important. ${ }^{\top}$ As Janice Bially Mattern has discussed, there is absolutely nothing soft about "soft power"-in the US case it is almost always used for the pursuit of "national interest," rather than because it is less coercive. ${ }^{8}$

What is necessary is an understanding of the specific mechanisms or modes of diffusion in the normative power approach and the roles they might play in EU public diplomacy (PD). In pointing to the different modes of diffusion in the normative power approach, Anna Michalski has suggested that "the strength of the EU's normative power is decided by its ability to shape other actors' perceptions of the appropriate cognitive content of international politics." $\mathrm{R}$ asmussen argues that "public diplomacy refers to the mechanisms of informational diffusion and the cultural filter diffusion" in the normative power approach. ${ }^{10}$ These different mechanisms or modes are discussed more extensively below.

The mainstream approach to describing PD as "winning hearts and minds" comes from the British role during the Malayan emergency of the 1940 s and $1950 \mathrm{~s} .{ }^{11}$ The phrase has subsequently come to be associated with the US misunderstanding of the Kampung Baru ("new village") counterinsurgency program and propaganda struggles of the Vietnam War. ${ }^{12}$ Thus in this chapter we look instead at the aim of sharing hearts and minds rather than winning them. This emphasis reflects the aim of moving the study of the EU as a global actor away from zero-sum winninglosing approaches towards understanding the role of the EU as sharing "European communion."

As Margot Wallstrom, the former vice-president of the European Commission, recognized in 2008 , the EU was rapidly moving from the old and relatively certain global order of the Cold War towards the new and relatively uncertain global order of the twenty-first century:

This is not an exercise in "national branding"; it is not "propaganda," because we know that this does not work. It is the recognition of a fundamental shift, and especially so in relatively open societies, of how power, influence and decision-making has spread, and how complex it has become. ${ }^{14}$

As the next five sections set out, this fundamental shift in the role of the EU in global politics requires a recognition of how the EU has "gone global" (section 2); how EU diplomacy is "going public" (section 3); how EU PD needs to consider "sharing minds" (section 4); how the normative power of $\mathrm{PD}$ can ensure the EU is "remaining distinctive" in global politics (section 5); and concluding on the normative power approach to the future of EU PD (section 6). The chapter concludes, in line with Wallström, that the fundamental shift of how power, influence, and decision making has spread and become complex demands the reconsideration of normative power and EU PD. The emphasis in this chapter is on the 
future of EU PD in a more globalized, multipolar, multilateral world. The chapter does not seek to explore the role of $\mathrm{EU}$ member states within this future shift but clearly, as Mai'a Davis Cross discusses in her chapter, if the EU and its member states are to have a future role at all, they must develop synergies not antergies in external actions and PD.

\section{Gone Global-The EU in Global Politics}

As any diplomatic service, the EEAS will consist of a central administration and EU delegations in third countries and at international organisations...Furthermore, the EEAS will consist of a number of geographic directorates general covering all regions of the world, as well as multilateral and thematic departments, a policy planning department, a legal department and departments for interinstitutional relations, information and public diplomacy.

The EU's imperative for engagement with the world beyond itself has deep roots and was an integral component of the earliest stages of European integration ${ }^{16}$ Being an innovative development in international relations-a regional organization that has sought to "go global" in the exercise of its influence - there is no previous model for it to follow. There is, however, a danger in being seduced by wanting to be a Westphalian post-Westphalian power: to want to play the games that states play rather than seeking to be an innovator in international relations. This tension between postmodern, post-Westphalian states can be found in the work of Thomas Diez and Robert Cooper. ${ }^{17}$ The debate regarding the ideal type of power the EU is being and becoming has been critically relevant over the past decade, with an emphasis on the four ideal types of "region-state," "liberal-internationalist," "civilian power," and "normative puissance."18

The EU has already established the panoply of instruments that any respectable state might want to run a foreign policy: a diplomatic infrastructure (embryonic, imperfect but in place), membership of key international organizations, a network of bilateral and multilateral relationships, and military power (albeit small but now with missions on the ground). More innovatively the EU has developed the novel approach of increasing its size by persuading third countries that membership is the only respectable course of action for a (post-)modern European state. As the excerpt from the 2010 Council decision on the European External Action Service (above) illustrates, the main elements of the EU's external actions include geographical and thematic diplomacy, together with information and PD. ${ }^{10}$ One immediate challenge for EU external action and PD is that responsibility for enlirgement still falls under the remit of the DirectorateGeneral for Enlargement of the European Commission. Another challenge is that the EU's desire in the 1990 s to improve relations with its nearest neighbors, who had no immediate prospect of membership, was 
scon overcome by the security discourses of the "war on terror" in the evolution of the European Neighborhood Policy, ENP. ${ }^{20}$

The EU thus has a very well-established relationship with its near neighbors - both prospective members and aspirants - but what of engagement with the world beyond? The EU has already "gone global" From early in its history it developed a network of association agreements and other forms of economic relationships. To these were added as "political dialogues" exchanges of views with third countries. Consequently embedded in the EU's foreign policy identity is this desire to remake the world - to create a negotiated order-largely through multilateralism. ${ }^{21}$ This network of stabilization and association agreements, the ENP, and Generalized System of Preferences "plus" (GSP+) arrangements all serve as examples of the EU's layers of institutionalized global relationships. In this respect, going global provides an opportunity for procedural diffusion and $\mathrm{PD}$ in the 20 association agreements identified by the EEAS in May 2011 -including Albania, Bosnia and Herzegovina, Chile, Croatia, Macedonia, Montenegro, Serbil, South Africa, Turkey, and the EuroMediterranean Association Agreements.

In 2003, the Earopean Security Strategy (ESS) placed multilateralism as the touchstone, and arguably the nison d'etre, of the EU's international presence. The ESS set out the strategic objective of effective multilateralism: "[i]n a world of global threats, global markets and global media, our security and prosperity increasingly depend on an effective multilateral system. The development of a stronger international society, well functioning international institutions and a rule-based international order is our objective." 22 The security strategy also contained a list of countries who were possible strategic partners, which was largely a list of great and emerging powers. As R ichard Youngs argued in 2005, many believe there is a need to harness EU power to promote objectives in a more concrete fashion and to make these relationships work in the EU's best interests. ${ }^{23}$ The ESS list included the United States, Russia, Japan, China, Canada, and India, but was also open to "all those who share our goals and values, and are prepared to act in their support." ${ }^{24}$ The list of strategic partnerships now includes ten countries: Brazil, Canada, China, India, Japan, Mexico, Russia, South Africa, South Korea, and the United States.

Atpresent thereis a huge commitment of time for the High Representative and vice-president of the European Commission, Catherine Ashton, in the conduct of EU diplomacy, but the direct benefits for the EU are not always apparent. While the creation of the EEAS was intended to relieve the routine aspects of diplomacy from the Commission and the Council, there are still unnecessary burdens for these two institutions and often with indeterminate effect. Examples include enlargement, negotiations, development cooperation, trade negotiations, international climate change negotiations, as well as the international economic and financial issues. Setting aside these capacity and coordination problems of making EU diplomacy work the EEAS, at best, aspires to create a twentieth-century 
diplomatic infrastructure in a twenty-first century world. The EU currently underplays the need to engage with peoples as much as states. As Mark Leonard and more recently Thomas Diez have argued, there is a need to build relationships with non-EU publics and civil society organizations. ${ }^{25}$ Having gone global with the Lisbon Treaty and the EEAS in 2010 , the EU is now going public with its diplornacy and public affairs.

\section{Going Public-EU Diplomacy and Public Affairs}

The main objectives under the Public Diplomacy part of the Industrialised Countries Instrument are to enhance the visibility of the EU as a whole, promote a better understanding of EU's actions and positions and exert a positive influence on how the EU is perceived in partner countries. This is done by supporting EU Centres, public policy think tanks and research institutes. Targeted events are organised in partner countries. This complements national initiatives which typically focus on the bilateral relationship with Member States. ${ }^{26}$

Despite the Lisbon Treaty and the creation of the EFAS, PD remains the Cinderella of the EU's global engagement. As the FFAS sets out (above). the main objectives of $\mathrm{PD}$ are to improve visibility, understanding, and perception of the EU in global politics. There is the need to strengthen the sharing of collective EU norms, identities, and values beyond the confines of diplomatic interaction. There is the pressing need to ensure that meaningful sharing of EU norms and values with those that should be reached the wider publics and civil society of third countries.

Since the creation of the EEAS and its PD objectives, a rapidly emerging literature has sought to both describe the conduct of PD and make recommendations regarding the development of its PD. ${ }^{27}$ However, what has been less discussed are the theoretical understandings on which the conduct and advocacy of the EU going public rest. As briefly discussed here, theoretical approaches regarding modernity, postmodernism, liberalism, superpower politics, and postcolonial theory are all implicated in a PD approach.

Robert Cooper has argued that the development of the EU's global presence demands the need to revert to the double standards of the colonial en if the EU is to engage effectively. In Cooper's terms, for "postmodern states," such as the EU, to conduct politics with "modern states," such as the developed world, may result in a qualitatively different form of relationship. ${ }^{28}$ According to this logic, pursuing EU policies though diplomatic tactics such as constructive engagement with third parties may appear to validate unsavory elites through those contacts. This was clearly the case in EU relations with the dictators overthrown in the 2011 Arab uprisings. ${ }^{27}$ For example, there was support of some EU member states 
for Ben Ali in Tunisia, Qaddafi in Libya, and Mubarak in Egypt. At the very least the EU needs to ensure that the publics of these third parties are aware that the EU is not legitimizing dictators with whom the EU is speaking. In short, the EU needs to work harder at what Kagan identified as Europe's strength in forging the relationships created with peoplesalongside EU connections with their governments. ${ }^{30}$

Clearly Cooper's type of approach is not without significant concerns regarding the primacy given to top-down traditional diplomacy over bottom-up PD, and the aims of security over democracy. ${ }^{11}$ As the Arab uprisings have illustrated, the EU cannot revert to a colonial view of modern and nonmodern peoples, but must instead encourage practices of joint or local ownership as a result of partner inwolvement and consultation. ${ }^{32}$

This is not "liberal mush," but rather would serve both an instrumental and a normative purpose. ${ }^{33}$ The attitudes of publics to US foreign policy across the globe between 2003-8 illustrated how not having a systematic approach to "sharing hearts and minds" in third countries generates a more difficult climate for the pursuit of interests and ideals. As Pew Research and other public opinion sources have made clear, once public support is lost, mistrust of the United States will persist in both Europe and the Middle East. ${ }^{34}$ This was not always the case for the United States. The power and influence that the United States exercised during the Cold War was comprised of a number of hard power components - military strength and alliances. However, as an important adjunct the United States created strategic shared value communities with allies (the "West") and acted tactically through the education of the elites of its allies through educational opportunities in the United States and the training of present and future military leaders. This created a unique reservoir of sympathetic elites: albeit one largely squandered over the last two decades.

The challenge for the EU is of course radically different to that of the United States during the Cold War. The EU is not engaged in an ideological or military struggle against an identifiable "other." Instead the struggle for EU PD, as the EEAS makes clear, (above) is to improve both the internal and external understanding of the EU; to make itself both heard and seen in an increasingly multipolar world; and to improve the perception of the EU in partner countries in the context of eurozone crisis and austerity politics. During the twentieth century former European metropols followed a similar practice to the US Cold War strategy of facilitating education for the nascent elites of the newly independent, postcolonial states. Education in the former colonial power still represents an attractive proposition to the successor generations of those in former colonies. For example, British Chevening scholarships, French Eiffel scholarships, and Commonwealth scholarships all provide opportunities for study in Europe. In the earlier colonial period education in the metropol provided the springboard for turning back the ideas of the colonizers against themselves in decolonial struggles (think of Mahatma 
Gandhi). The normative potential of generating such "social independencies" is considerable, although there is also clearly a risk of sustaining postcolonial hegemony.

These theoretical approaches of postmodernism, state-centrism, liberalism, and postcolonialism all illustrate the potential benefits and risks of EU PD. In contrast, the rest of this chapter will articulate a normative power understanding of the EU diplomacy and public affairs in "going public." Working within critical social theory the normative power approach seeks to understand the interrelationships between material and nonmaterial forms of power in global politics. It attempts to understand whether and how physical and material forms of force and incentives are separable from nonmaterial forms of ideational power. To interrogate this possibility the approach distinguishes between three forms of power-physical force, material incentives, and normative justification. Conceptualizing normative power as ideational nonmaterial justification involves a threepart understanding of its use and analysis linking principles, actions, and impact. As the next section will now illustrate, a normative power approach to analyzing EU PD is facilitated by distinguishing between six modes or mechanisms of diffusion. ${ }^{35}$

\section{Sharing Minds-EU Public Diplomacy}

Public diplomacy acquires particular importance in the context of the new EU diplomacy. This is very much related to the fact that the EU formulates its policy in public and that secrecy is inimical to its way of decision making, thus raising the need for information and communication... Indeed, a notable dimension of EU diplomacy is its transformative nature as the EU is a normative power focusing on the promotion of its values and normative framework. ${ }^{36}$

Josep Lloveras Soler, a former head of delegation at the European Commission, has argued that new EU diplomacy needs to learn to add value in the post-Lisbon period. He adds that a notable dimension of EU PD is the normative power of formulating policy in public, rather than secret. As summarized by Anna Michalski, ${ }^{3 /}$ the normative power approach identifies six different ways in which policy and norm diffusion takes place: (i) contagion (unintentional diffusion); (ii) the informational mode through strategic communications; (iii) the procedunal mode through institutionalized contractual agreements with third parties; (iv) tranference through exchanges of goods, aid, trade, or technical assistance; (v) overt diffusion through the physical presence of the EU abroad; and (vi) the cultural filter leading to the construction of knowledge by third parties. This framework will now be used to understand the sharing of minds through EU PD. 


\section{Contagion}

The contagion diffusion of norms takes place through the diffusion of ideas between the EU and the rest of the world. The discussion of historical precedence in the previous section suggests there are lessons to be drawn here for the EU as a "European communion." The EU needs to devote greater attention to producing "value interpreters" in third countries - those individuals and social actors who have developed an intuitive understanding of EU norms and values, how these impact upon the development of political and social institutions in the EU, and how they impact on an EU worldview. As an equal partner to EU diplomacy it needs to ensure that there is a reservoir of understanding in third countries as to the purposes to which short-term dipiomatic decisions are intended to eventually lead. In this way PD is a means of sharing minds with others through promoting the contagion of ideas, understandings, and perceptions.

\section{Informational}

The informational diffusion of norms occurs through references to a range of strategic communications such as new policy initiatives by the EU, and declaratory communications such as initiatives from the High Representative or the president of the Commission. Drawing on Umberto Eco's idea that "translation is the language of Europe," Furopean Commissioner Leonard Orban has argued that for the EU

a society is multilingual not only when its citizens can speak different languages, but also when its languages maintain a constant communication through translation. Translation is indeed a continuous negotiation between the author, the translator and the reader. In Europe, we know this only too well, negotiation being the very essence of our staying together. ${ }^{38}$

Hence, the emphasis on value interpreters, value translation, and contimuous negotiation is important for both the sharing of the EU amongst members and sharing minds through PD. However, this is not to create apologists for an EU foreign policy, which will not always constitute international best practice. Rather, it is to avoid a repeat of the experience of the United States, which has witnessed an ongoing decline in the number of "value interpreters" willing to even-handedly critique its foreign policy. Value interpreters are political and social commentators, and those with the respect of publics, who are willing to interpret EU actions in an open-minded manner. From this informational diffusion perspective, the purpose of $\mathrm{PD}$ is to ensure that interpreters and translators are able engage in a continuous negotiation regarding the EU in public settings outside Europe. 


\section{Procedusal}

The procedural diffusion of norms takes place through the institutionalization of relationships between the EU and third parties, involving political partnership as found in interregional cooperation agreements, membership of an international organization, association agreements, or enlargement of the EU itself. There are three procedural ways in which the EU can seek to build a body of value interpreters: first, to bring people to the EU; second, to give greater attention to EU "value translation"; and third, to ensure that such interpretation and translation remains a two-way communication process. These are the processes through which European values are experienced, translated, interpreted, and reflected on. There is already a considerable intellectual exchange between EU states and third countries. Shorter and longer duration migration has provided an important pool of value interpreters as migration to and from postcolonial societies have created kinship links that generate the sharing of ideas between states and societies outside the EU. Scholarships and educational exchange opportunities are structured approaches to facilitating the exchange of ideas. All of these are important and provide an informed "inside" view of European societies and facilitate the view that collective EU attempts to engage with the world beyond the EU are not inspired by malicious and malevolent design. The procedural institutionalization of relations provides opportunities for sharing minds with others through two-way partnership and communication processes. For example the EU's Visitors Program, established in 1974, facilitates short visits to the EU institutions from over 170 countries around the world. ${ }^{3 / 3}$

\section{Transference}

The transference diffusion of norms occurs when the $\mathrm{EU}$ is involved in the transfer of material and immaterial assets such as humanitarian aid and technical assistance, but is equally likely to be the result of more "grass roots" engagement of EU agencies and support for NGOs on the ground. There is more that can be done through public policy and transference to facilitate greater numbers of value interpreters. The "humane" handling of visa applications for travel to the EU and less daunting entry-point experiences do not conflict with appropriate border control arrangements and travel restrictions but would give the EU a competitive advantage over the present and future arrangements that prevail in the United States. The Erasmus and Socrates education exchange programs are a remarkable success story in having facilitated university student exchanges from member states and applicant states in creating social bonds within an EU of 27. The number of Erasmus students exchanged has gone from three thousand in its first year (1987) to a total of three million over the 26 year period to $2013^{40}$ There are minor educational initiatives attached to existing trade and aid agreements with third countries and the EU 
needs to approach these more strategically and systematically. The need to use these to stimulate greater society-to-society contact as an adjunct of EU diplomacy was recognized in the creation of the Erasmus Mundus program beginning in 2004. Between 2004 to 201214,000 students from around the world have studied on Erasmus Mundus masters courses. Such transference diffusion facilitates a deeper sharing of minds than almost any other form of PD. There are similarities to traditional exchange programs such as EU and member state visitors programs, but are believed to have a deeper effect through earlier and more sustained sociocultural experiences. Whether it is the "Erasmus generation," "Erasmus generation 2.0," or the "Erasmus Mundus generation" that is being facilitated through PD transference, the longer-term consequences will take more than a generation to recognize."

\section{Overt}

The overt diffusion of norms occur as a result of the physical presence of the $\mathrm{EU}$ in third states and international organizations, with the most obvious example including the role of EEAS delegations in third countries and at international organizations. The overt presence of EU PD goes beyond EEAS delegations to include the roles of the High Representative herself and the special representatives. As Catherine Ashton's statement on the European Parliament's Salafranca report illustrates, for the newly appointed special representative on Human Rights "communications and public diplomacy will be also be key. The EUSR should help us to be more visible and to promote human rights across the whole range of the EU's external policies. ${ }^{42}$

It is also possible to go further with in-country cultural diplomacy and in-country education. In-country cultural diplomacy goes beyond the role of FFAS delegations in third countries generating publicity about the practices and policy of the EU. What is needed is a more sustained and reflective approach to the sharing of ideas and information about cultures and peoples between and with the citizens of third countries. Censorship and other forms of control of information in third countries often ensure that peoples are not well served by the information that they possess on the EU. Such barriers to entry can be tackled by the same manner in which European industry has approached barriers to entry in important markets - by "outsourcing" to those third countries. The EU needs to enhance its presence in third countries to create value interpreters. The models of the Alliance Francaise, British Council, Goethe-Institut, Instituto Camòes, Instituto Cervantes, and Società Dante Alighieri are instructive in that their work in third countries generates remarkable loyalty and affection through their educational and cultural activities. The EU needs a comparable but more active presence in third countries. The creation of the network of European Union National Institutes for 
Culture (EUNIC) in 2006 marks a first step towards more overt public and cultural diplomacy. The EUNIC is made up of 29 members from 24 of EU member states in a network of intemational cultural relations institutes working in over 150 third countries with over 2,000 branches. ${ }^{43}$

\section{Cultusal Filter}

The final factor shaping and transforming the diffusion of EU norms is the cultural filter. The cultural filter is based on the interplay between the construction of knowledge and the creation of social and political identity by the subjects of norm diffusion. ${ }^{44}$ The cultural filter involves a number of mechanisms of identity, domestic salience and the construction of knowledge, including persuasive engagement, venues for dialogue and argument, and the transference and status of ideas. As the brief discussion of the five previous modes or mechanisms of PD diffusion illustrate, the cultural filter presents the greatest challenge for EU PD. For this reason, it might be suggested that as an adjunct to the EU's Instrument for Stability that promotes the strengthening of law and order in third counties the EU needs to be able to deploy a longer-term presence that promotes civil society "best practice" through education and the promotion of the free exchange of ideas. While the Instrument for Stability is specifically focused on conflict prevention, crisis management, and peace building, its crisis management activities give support to mediation, confidence building. interim administrations, strengthening rule of law, transitional justice or the role of natural resources in conflict. This presence could take place through the creation of a network of European "progressive foundarions," similar yet different to the US "freedom houses," which would support governance best practice, the role of the media, social institutions, and the role of the state in democratic societies. This would take place by providing both the means to facilitate the gathering of intellectuals and other social actors within the "progressive foundation" host country, from the neighboring countries and regions, and to bring individuals and organizations from the EU member states, and beyond, to exchange experiences and ideas. There is clearly the expectation that such foundations would not be positively received in all host societies, particularly those with authoritarian governments. There are at least two routes to engaging with this expectation: first to ensure that foundations are nongovernmental organizations that work with and through both host and (non-European) regional organizations, NGOs, and civil societies. The second route is to encourage reciprocity with host governments and societies in the setting up of their partner foundations within the EU.

An immediate response to this idea might be to question "which" Europe is being promoted? it was not, however, difficult to measure and promote the "Copenhagen criteria" for applicant states. Since the Lisbon Treaty, it has become easier to decide which EU norms and values 
to support and promote in third countries. The consolidated Treaty on European Union now identifies a catalogue of principles in articles 2 and 3 , in particular freedom, democracy, human rights, rule of law, equality, solidarity, sustainable development, and good governance. Natalia Chaban's work on popular opinion has identified how Asian news media professionals already see some aspects of the EU's normative power through its promotion of freedom, democracy, human rights, equality, and the environment. ${ }^{55}$ The capacity of EU governments and societies to facilitate the rights and cultures of minorities is an obvious norm to support and promote in third countries, for example. Care and consideration will need to be exercised alongside principles and commitment with some governments and societies, which will be reluctant to see their control over information relinquished.

Although support for EU "progressive foundations" in third countries would be controversial, they may be facilitated by the newly created European Endowment for Democracy (EED) which, in the European neighborhood will assist:

pro-democtatic civil society organisations, movements and individual activists acting in favour of a pluralistic multiparty system regardless of their size or formal status. The EED will also provide assistance to young leaders, independent media and journalists, provided that all the beneficiaries adthere to core democratic values and human rights as well as subscribe to principles of non-violence. ${ }^{46}$

A regional-based approach to the idea of an overt presence to address the cultural filter could also encompass a network of EU universities shared with each region. During times of economic crisis and the ideology of austerity there will be resistance to the costs of educational expansion. But $\mathrm{EU}$ member state universities have been busy setting up satellite university campuses around the world over the past two decades for commercial reasons. In this case, as with local and community colleges around the world, the longer-term educational, social, and commercial benefits need to be argued for both the EU and the host society. There are antecedents to this with the 32 EU Centers of Excellence spread around the developed world in the United States, Canada, Japan, Korea, Australia, Russia, New Zealand, Singapore, and Taiwan. Within the EU the European University Institute Forence (Italy). College of Europe Bruges (Belgium), and Natolin (Poland) all serve as examples of EU colleges. Such EU university colleges could be initially located in China, Central Asia, Sub-Saharan Africa, and South East Asia. These would not be institutions to teach "European integration" as is the focus of current EU educational initiatives in third countries. Nor should they be "full-spectrum" universities engaged in all of the scientific and technical pursuits as other EU universities are already creating such satellites in third countries. Rather their central remit would be as schools of 
public administration, law, journalism, and civil-military relations, not unlike the role of the Central European University created in 1991 to support the democratic transitions in Europe and Central Asia. Clearly, the governments of some developing countries of Asia and Africa have concerns about the idea of "democratic transition" being taught in local colleges and universities. Hence the importance of engaging with local and regional civil societies and NGOs in host countries to help clarify the developmental benefits of such education to host governments.

Their purpose would be to offer short-and long-term education to the next generation of top civil servants, lawyers, judges, journalists, and the senior military personnel. The curriculum would be devoted to examining how such professions are organized and practiced across the member states of the EU. Once established, the independence of content and functioning of these universities, as well as the progressive foundations, would have to be maintained diligently by local civil society, the EU, its member states, and regional partners involved in the establishments. By supporting the establishment of progressive foundations and shared university colleges, EU PD could provide a means of sharing minds with others by actively engaging with the cultural filters of identity, domestic salience and the construction of knowledge in a local context.

\section{Remaining Distinctive-The Normative} Power of Public Diplomacy

Foreign policy in general has had the tendency to pretend to start from a coherent identity but in fact only constructed this identity in the process. It may be a unique character of the EU (indeed as a normative power) to celebrate diversity, and thus in contrast to the standard practice, it may be a core point of EU public diplomacy to "sell" and engage with different values and policy stances rather than to impose coherence when there is none. ${ }^{47}$

The chapter has argued how, in the context of the Lisbon Treaty and creation of the EFAS, the "fundamental shift" in global politics identified by Margot Wallstrom demands the consideration of the normative power approach when thinking about EU PD.

In this context, the EU needs to become more active in its approach towards $\mathrm{PD}$ where focusing upon value interpreters and value translators operating in third countries is crucial. If the practice of EU diplomacy is to be more fully understood in third countries there is the need to be more active in ensuring that there is an audience aware of the EU's aspirations. This does require an active form of engagement that is itself intended to facilitate the greater exercise of EU normative power. It will not be an approach that will yield quick results but is an essential component of smoothing the path of the EU as its goes global. 
The chapter has further set out, following Wallström and Birchfield, that normative power and PD are interlinked through the dialectic of being ("what we are and what we stand for") and becoming ("what we do or want to do"). In this respect the chapter has suggested that EU PD should seek to share its values and objectives such as the more liberal norms of freedom, democracy, human rights, and the rule of law, together with the more social norms of equality, solidarity, sustainable development, and good governance.

However, as Diez has suggested it may also be worth considering a further norm worthy of promotion through the practice of EU PD - that of diversity. Diez argues, alongside Wallstrom and Birchfield, that the construction of identity through the practice of foreign policy and $\mathrm{PD}$ is one of becoming, rather than pretending a coherent identify of being from the outset. In this respect he argues that the EU as a normative power needs to celebrate diversity in its PD- that it is not quite sut generis enough in attempting to engage with different values internally while imposing coherence on EU values externally. ${ }^{48}$ Diez's advocacy of diversity and dialogue in EU PD is in line with the observation that the principle of subsidiarity can provide "a shared raison d'être where the Union acts to better achieve together what cannot be achieved apart." In this context it is worth reflecting on the idea that the normative power of EU PD may lie in remaining distinctive by not copying the traditional twentieth-century diplomacy and PD of states, but developing the inherent EU capacity for diversity and dialogue among 28 member states as a means of engaging in a more pluralist twenty-first century world of multipolarity and multilateralism.

\section{Conclusion}

First, this chapter has argued that the study of the EU's public policy can benefit from, indeed demands, a normative power approach to understanding the power of ideas in global politics. Second, it has been suggested that having "gone global" with the Lisbon Treaty and EEAS, a normative power approach can help thinking about the relative importance and use of traditional and/or PD. Third, the chapter has set out how the normative power approach to theorizing EU diplomacy and public affairs can be useful as the EU is increasingly "going public." Fourth, the main analysis of the chapter used the six modes or mechanisms of diffusion of the normative power approach to understand how EU PD could move toward "sharing minds" through engagement, dialogue and presence in third country societies. Fifth, the chapter has reflected on the value of subsidiarity and diversity in the fundamental shift of being and becoming when the EU practices PD.

As has been developed throughout, a normative power approach to the future of EU PD moves the emphasis away from imitating twentieth- 
century traditional diplomacy and towards creating a more distinctive and appropriate twenty-first century PD. This normative power approach has suggested the need to move away from imitating US "soft power" for the pursuit of EU "supranational interests." In this respect, the traditional emphasis on the Cold War propaganda war of "winning hearts and minds" has been rejected in favor of sharing hearts and minds. This rejection of "national branding" or "propaganda" through soft power is in recognition of the fundamental shift of twenty-first century politics of how power, influence, and decision making has spread and become more complex. For the future of EU PD the fundamental shift is clear-there is a need to build relationships with non-EU publics and civil society organizations. This has been painfully demonstrated through the Arab uprisings, where the traditional paradigm of security, national interest, and diplomacy justified maintaining relations with authoritarian dictators. In contrast a normative power approach with an emphasis on sharing minds through EU PD suggests how to develop the six different mechanisms or modes of diffusion through contagion, information, procedure, transference, overt presence, and engagement within the cultural filter. In condusion the normative power of $\mathrm{PD}$ can help the EU in "remaining distinctive" because "the EU needs to be unambiguously a normative power demonstrating that visions of the future for our neighborhood and in global politics more generally cannot be expressed adequately in either economic or security terms but need to be leavened with ideas, opinions, and issues of conscience." 50

\section{Notes}

*We are very grateful for the helpful comments of Mai'a Davis Cross, Jan Melissen, Simon Dake, Patrick James, and Ceoffrey Pigman.

1. Margot Wallatröm, "Public Diplomacy and les Role in the EU"s Fixternal Relations," speech to the Mortara Center for International Sturibes, Georgetown University. Washington DC, SPEECH/08/494, Octuber 2, 2008, 2-3.

2. In Manners, and Richard Whitman, "Towant Identifying the International Identity of the European Union: A Framework for Analysis of the EU's Network of Relations," Jowrnal of Eiunpeom Intognaion 21, no. 2 (1998): 231-49; Ian Manners and Richard Whitman, "The 'Difference Engine': Constructing and Representing the International Identity of the Iiurupean Unian," Joumal of Furopean Public Policy 10, na. 3 (2003): 380-404; Richard Whitman, Foom Civitian Pown to Superposar? The Intrmational Identity of the Liuropom Linion (Basingstoke: Macmillan, 1998).

3. Ian Manners, "Normative Pewer Europe A Contradiction in Termaz" Joumal of Common Market Studies 40, no. 2 (2002): 235-58; lan Manners, "Assessing the Decennial, Reassessing the Clabal: Understanding Furupean Union Normative Power in Global Politics," in Richard Whitman and Kalyposo Nicolañdis (eds) "Furopean Union and Normative Power: Assessing the Decade," Special Issue of Coopenation and Cooffict 47, no. 2 (2013): 304-29; Richard Whitman (od), Nammatise Power Fiunpe: Empinical and Theoretical Perpectives (Busingsteke: Palgrave, 2011); Richard, Whitman, 
and Kalypeso Nicolnidis (eds.), "European Union and Normative Power: Asvessing the Derade," Special lssue of Coopention and Conflit 47, no. 2 (2013): 167-329.

4. Vicki Birchfield, "A Normative Power Iiuroge Framework of 'Transmational Policy Formation," Joumel of Eumpain Public Policy 20, no. 6 (2013): 907-22; also Manners and Whitman, "Difference Engine": 381 .

5. Desamond, Ben, "Three Ways of Speaking Furope to the World- Markets, Peace, Cosmopolitan Daty and the EU's Normative Power," British Joumal of Politicr and Intemational Relations 15 (2013).

6. Steffen Bay Rasmussen, "The Messiges and Prattices of the European Union's Public Diplomacy."The Hagne joumal of Diplomacy 5 (2010): 266.

7. Ibid.

8. Thomas Diez, and Ian Manners, "Reflecting on Normative Power liurupe," in Pourer in World Politios, ed Felix Berenskoetter and Michael J. Williams (London: Routlodge, 2007), 179.

9. Janice Bially Mattern, "Why "Soft Power" Isn' So Soft: Representational Force and Attraction in World Politica," in Power in World Politior, ed Fehix Berenskotter and Michael J. Williams (L.andon: Routledge, 2007).

10. Anna Michalski, "The EU as a Soft Perwer: the Foree of Persaasion," in The New Pudlic Diplomacy, ed, Jan Melissen (Basingstoke: Palgrave, 2005), 127.

11. Rasmussen, "The Messages and Practices,"

12. Kumar Ramakrishna, Eimengency Propapunda: The Winnüg of Maliryan Hasnt and Minds 1948-1958 (Londan: Routledye, 2001).

13. Peter Davis (dir) Heants and Minits (BBSS Prodartians, R ainbow Releasing, 1974); Neil Sheehan, A Bright Shining Lie John Pal Varm and Ameriar in Vietnum (London: Pimlica, 1995).

14. In Manners, "European Communior: Political Theory of Furopean Union," Journal" of Eivopean Public Policy 20, no, 4 (2013): 473-94.

15. Wallstrōm, "Public Diplomacy and lts Roic," 2

16. Council ofthe European Union, "EEAS Decision-Main Elements,"MFMO/10/311, Brussels, July 8,2010 , 1 .

17. Dirk Spierenhurg and Raymond Poidevin, The History of the High Authority of the Eanopean Coal and Steed Commanity. Supnunationality in Opecation (London: Weidenfeld \&. Nicolson, 1994).

18. Thomas Diez, "International Ethics and European Integration: Federal State or Network Horixon?" Aliemative 22, no. 3 (1997): 287-312; Rohert Cooper, The Bmakinge of Nations (L.andon: Atlantic Boskss, 2003).

19. Ian Mannen, "The European Union's Normative Power in Clobal Politics," in Key Controvenier in Furopenn Integnation, ed. Andress Dür and Hubert Zimmermann (Busingstoke: Palgrave, 2012), 192-9.

20. Council of the Europesn Union, "Council Decision Establishing the Organisation and Functioning of the Furopean Fixternal Action Service" (2010/427/EU), Offiall foumal of the Fiuspean Union, L. 201/30, 3.8.2010,

21. Iris Kempe, Dimet Neiphtowmood; Relations heturen the Finlangod EU and the Russian Fedenation, Ulowine, Relanes and Moldowa (Cuntersloh: Bertelsmann Funndation, 1998); Lucia Padure, Andrew Williams and lan Manners, The Republic of Moldovar Time for a New EU Sinutegy? (Brussels: SWP-CPN Selected Contributions No. 5, 1999); Ian Manners, "As You Like It: Furopean Union Narmative Power in the liuropean Neighbourhood Policy," in The Firnopean Neiphtbourhosd Policy in Pexpective: Context, Impiementation and Impart, ed. Richand Whitman and Stefan Walff (Basingstoke: Palprave, 2010, 29-50. 
22. Michael Smith, "The Furopean Uniwa and a Changing Europe: Fistablishing the Boundaries of Order," Joumal of Common Markert Studies 43, no. 1 1996): 5-28.

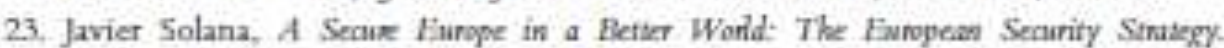
Approwed by the European Council held in Brussels on December 12, 2003 and drafted under the responsibilities of the EU High Representative Javier Solama, 9.

24. Richard Youngs, "Fingagement, Sharpening Furopean Influence," in Clabul Elumpe: New Terms of Ensogement, ed. Richard Youngs (1 andon: Forcign Policy Centre, 2005), $\mathrm{t}-14$

25. Solata, A Secure Eismope in a Betier World, 14.

26. Mark Leonari, Pullic Diplomacy (Landon: British Council/Foreign Policy Centre, 2002): Thomas Dier, "The fiuropean Union's External Action Public Diplomacy and Discourse," background note prep̧ared for Agora Forum: Research Networks, Civil Society, Policy Makers, Foundation Universitaine, Brussels, February 28, 2013.

27. European External Action Service, EFAS, "public Diplomacy," 2013, hup://eeas. europa.eu/ici/publictiplomacy/index_en.htm

28. Rasmussen, "The Messages and Practices"; Paul Sturm, and Giji Gya, "Shoring up the EU's Puhlic Diplomacy in CSDP," Fumpean Security Review, no. 52 (November 2010), International Security Information Service, Europe; Simon Duke and Aurélie Courtier, The EU's External Public Diplomacy and the EEAS; Cosmetic Exercise or Intended Change? Loughborough: Jean Monnet Network on the Diplomatic System of the European Union, Policy Paper 2011, No. 7.; Megan Kenna, "Social Media: Following EU Public Diplamacy and Friending MFNA, Furopoin Policy Centre Pobicy Brief (July 2011); Josep Loveras Soler, "The New EU Diplanacy: Learning to Add Valve," European University Institute Working Papers, Robert Schaman Centre for Advanced Studies, 2011; Sieglinde Gstähl, "Earopean Union Diplomacy: What Rele for Training?," EU Diplomacy Papers 3/2012, Department of EU International Relations and Diplomacy Studies, College of Europe, Hragge; and Diez, "International Eithics and European Integration."

29. Cosper, The Brasking of Nations, 40-1.

30. Kenna, "Social Media."

31. Robert Kagan, Of Puradise and Power. America and Kumpe in the Nav World Onier, (New York: Alfred Knopf, 2003) 5, 5i.

32. Marners, "As You like It," 30.

33. Ibid., 43-4; Ian Manners, "The European Union's Normative Puwer: Critical Perspectives and Perspectives on the Critical," in Normative Power Europe: Empinical and Theoretical Perspectives, et. Richard Whitman (Basingstoke: Palgrave, 2011), 238.

34. Chris Patten, "Engagernent is Not Liberal Mush," New Perspentives Quarienly 19, no. 2 $(2002): 36-8$.

35. Pew Research Center, "A Year After laq War: Mistrust of America in Eurupe Ever Hiyher, Muslim Anger Persists," March 16, 2004. http://people-press.org/reports /display php.32ReportID-206

36. Ian Mannen, Normative Pouver Fiunope A Contnatiction in Tenws?, Copenhagen Peace Research Institute, Working Paper 36/2000, pp, 35-6; Manners "Normative Power Furope," 244-5; Manners, "Assessing the Decennial," 314-5.

37. Soler Loveras, "The New EU Diplamacy," 9.

38. Michalski, "The EU as a Soff Pewwer," 143.

39. Faropenn Conmission, "The Contmission Orpanises a Debate in Arusels on Translation, "The Laniguage of Eurupe", IP/08/1631, Brussela, Novernber 5, 2008, 2. 
40. Scoth-Senith, Giles, "Mending the "Unhinged Alliance" in the 1970S: Transatlantic Relations, Public Diplomary, and the Origins of the European Union Visitors Program," Diplomacy \& Statinsest 16, no. 4 (2005): 749-78; European Fixternal Action Service (EFAS), "Fiuropean Union Visitors Program," Delegation of the fiuropean Union to the United State of America, 2013. http///wwwevinthieus.org/what-you -can-do/participate-in-our-programs/european-union-visiton-program/

41. European Commission, Lifelang Learning Propramme, The Enamais Progoumme 20102011, A Statictioal Ovenview (Brussels: DG Edaration and Training, 2012), 14.

42. Lain Wilson, "What Should We Expect of 'Eraemus Generations'?" Joumal of Common Murket Siudier 49, no. 5 (2011): 1113-40; Annelies Messelink and Jan D. ten Thije, "Unity in Super-Divenity: Furopean Capacity and Intercultural Inquisitiveness of the Frasmus Generatisn 2.0," Dutoh Joumal of Applird Lingristicr 1, no. I (2012): 80-101; Christine Lloyd, "The Firasmus Mundas Programme; Providing Opportunities to Develop a Better Understanding about Inclasion and inclusive Practice through an International Collaborative Prograntme of Strody, International Joumal of Indusive Education 17 , no. 3 (2013) $329-35$.

43. Catherine A saton, "Statement on Salafranca Report-EUSR on Human Riphts," to the European Parliament, Strasbourg, SPEECH/12/433, June 12, 2012.

44. European Union National Institutes for Culture (FUNIC), EUNIC Yeurbook

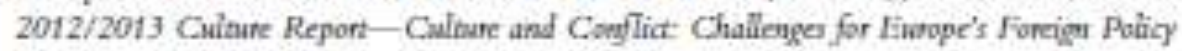
(Stuttgart: Institute for Foneign Cultural Relations, 2013).

45. Catarina Kinnvall, Cuthund Diffurion and Political Launing The Demacnativation of China (l.und: Iund University Press, 1995), 61-71.

46. Natalia Chaban, "Imagr-ing the EU as an International Leader. A Sarvey of Asian Newsmakess" Perceptions from a Public Diplonacy Perspective," Eunopean Foreign Affair Revies 17, no. 1 (2012): 80-1.

47. Council of the Furopean Union, "Declaration on the Fistablishment of a European lindawment for Demacracy," 18764/11, Hirussels, December 20, 2011, p, 3.

48. Diez, "The European Union's External Action," 2.

49. Thomas Diez, "Not Quite "Sui Generis" Enought: Interrogating Furopean Valves," Eunpom Socinties, 14, na. $4(2012)$ : 522-39.

50. Manners "European Communion," 487.

51. Richand Whitman, "Europe Has to Become a Change-Maker in Clabal Politics," ErShaty (July 4, 2011): hatp://www.esharp.ev/Web-specials/lurope-has-to -become-1-change-maker-in-global-politics

\section{Bibliography}

Ashton, Catherine. "Statement on Salafranca Report-EUSR on haman rights, to the European Parliament." Strasbourg, SPEECH/12/433, June 12, 2012.

Barroso, José Manuel. "Furope's Rising Clobal Role." The Guandian, January 3, 2010.

Barrusa, José Manuel. "Furupear Union: An Indispensable Partner." Speech by President Barroso at Princeton University, SPEECH/12/650, September 12, 2012.

Basker, Fimma. "Eiuropean Union Public Diplomacy." In The Present amd Future of Phathic Diplomany. A European Perspective, The 2006 Mainid Conference on Pablit Diplomacy, edited by Javier Noya, 31-3. Madridt Real Instituto Flano, 2005.

Birchfield, Vidki. "A Normative Power Fiarope Framework of Transnational Policy Formation." Joumal of Eumopean Publit Policy 20, no. 5 (2013): 907-22. 
Chaban, Natalia. "Imag-ing the EU as an International Leader A Survey of Asian Newsmakers' Perceptions from a Public Diplomary Perspective." Finopoun Fonign Affairs Review 17, no. 1, (2012): $69-92$.

Cooper, Robert. The Breuking of Nations. Lundon: Atlantic Books, 2003.

Counct of the Furopean Union. "EEAS Decision-Main Elements," MEMO/10/311, Brusseks, Jaly $8,2010$.

Council of the European Union. "Council Decision Establishing the Oryanisation and Funtioning of the liaropean External Action Service," (2010/427/EU). Official Joumal of the Fiuropern Lnion L 201/30 (August 3, 2010).

Coanctl of the European Umion. "Declaration on the Fistablishment of a European Endowment for Dernocracy," 18764/11, Brussels, Decemher 20, 2011.

Davis, Peter (director). Heartr and Minds. BBS Productions, Rainhow Releasing, 1974.

Diez, Thomas. "International Fithics and Funopean Integration; Fiederal State or Network Horizon?" Alsematives 22, no. 3 (1997): 287-312.

Diez, Thomas, "Not Quite "Sui Ceneris" Enough: Interrogating Furupean Valoes," Eunopean Societier 14, no. 4 (2012): 522-39.

Diex, Thomas "The Furopean Union's Extermal Action Public Diplomary and Discoune" Background note prepared for Agora Forum: Research Networks, Civil Society, Policy Makers, Foundation Universitaine, Brussels, Fubruary 28, 2013.

Diez, Thomas, and Ian Mannen. "Reflecting on Normative Power Furope," In Power in World Politiss, edited by Felix Berenskoetter and Michael J. Williaens, 173-88. London: Roatledge, 2007 ...

de Gouveia, Philip Fiske, with Hester Plamridge Eunopean Infopolitik: Desdoping IU Public Diplomacy Strangy. Londoa : The Foreign Policy Centre, 2005.

Duke, Simon and Aurélie Courtier. "The EU's External Public Diplomacy and the EEAS: Cosmetic Fixercise or Intended Change?" Loughboroagh: Jean Monnet Network on the Diplounatic System of the European Union, Palicy Paper No. 7, 2011.

Furopean Commissian. "The Commission Organises, a Debate in Hrussels on 'Translation, "the language of Europe'," IP/08/1631, Brussels, Nowember 5, 2008.

European Commission. Liffelong Leaning Prognamme. The Enumus Prognumme 2010-2011, A Statistisal Ovenrin. Prussels: DG Fdacation and Training. 2012.

EuropeanFixtemalActionService(EEAS). "PublicDiplomary,"2013.http://eeas.europa.eu/ici /publindiplarnacy/index_en htm

European Extemal Action Service (EEAS), "European Union Visitors Program." Delegation of the European Union to the United State of America, 2013. http:// www-euintheus.org/what-you-can-do/participate-in-our-programs/europeanunion-visitors-program/

Funapean Union National Institutes for Culture (EUNIC). EUNIC Yearhook 2012/2013 Culture Report-Chatuse and Comflict: Challenges for Fisuope's. Foneign Policy. Stuttgart: Institute for Foreign Cultural Relations, 2013.

Gstohl, Segrlinde. "Fiuropean Union Diplomacy: What Role for 'Training?", EU Diplamacy Papers 3/2012, Department of EU International Relations and Diplomacy Stadies, Callege of Europe, Arupge.

Kagan, Robert. Of Pandise and Power: America and Furope in the New World Ondec New York: Alfred Knopf, 2003.

Kempe, Iris. Direct Neighbourhood: Relations between the Enlarged BU and the Rressian Fedenation, Ukaine, Bdanes and Moldowa. (Guterslohs Bertelsmann Foundation, 1998).

Kenna, Megan. "Social Medix: Following EU Public Diplomacy and Friending MIINA.European Policy Centre Policy Brief (July 2011). 
Kinnvall Catarina. Cultund Difrerion and Potitical Leaming: The Democnumsation of China. I und I and University Press, 1995.

Leonand, Mark. Puhlic Diplomacy. London: British Council/Foneign Policy Centre, 2002.

Lloweras Soler, Josep. "The New EU Diplumacy: Learning to Add Valse," Eurupean University Institute Working Papers, Robert Schuman Centre for Advanced Studies, 2011.

Inyd, Christine "The Erasmus Mundar Programme: Providing Opportanities to Develop a Better Understanding about Inclusion and Inclasive Practice through an International Collaborative Programme of Study." Intenserional Joumal of inclusive Eiducation 17, no. 3, 2013): $329-35$.

1.ynch, Dov. "Communicating Purope to the World: What Public Diplomacy for the EU?" EPC Warking Paper no. 21, Navember 2005.

Manners, lan. "Normative Power Farope: A Contradiction in Terms?" Copenhagen Peace Research Institute, Working Paper 38/2000.

Manners, Ian, "Nomative Power Furope: A Coniradiction in 'Termse," Joumal of Common Market Souties 40, no, 2, (2002):: 235-58.

Manners, Ian. "As You Like It: European Union Normative Power in the Furopear Neighbourbood Policy." In The Eucopean Nerghbourhood Policy in Perspertise: Context, impiementation and bespact, edited by Richard Whitman and Stefan Wolft, 29-50. Basingstoke: Palgrave, 2010.

Manners, Ian. "The European Union's Narmative Power: Critical Perspectives and Perspectives on the Critical." In Normative Power Euinipe Empinical and Thenretial' Perpectives edited by Richard Whitman, 226-47. Basingroke: Palgrave, 2011.

Manners, lan. "The Earopean Union"s Normative Power in Clobal Politica" In Key Controversies in Furopean Integnation, edited by Andreas Dür and Hubert Zimmermann, 192-9. Busingstoike: Palgrave, 2012.

Manners, Ian. "Assessing the Decernial, Rexsesaing the Clobal: Understanding European Union Narmative Power in Clobal Politirs." In European Union and Normative Power: Assessing the Decade. Special kssue of Coopenation and Conflict 47, no, 2 (2013): 304-29.

Manners, Ian, "European Comumunion: Political Theory of Furopean Union." Joumal of Eivopoun Public Policy 20, no: 4 (2013): 473-94.

Manners, Ian and Rirhard Whitman. "Towands Identifying the International Identity of the Furopean Union: A framework far Analysis of the EU's Network of Relations." Joumal of European lintegration 21, no. 2 (1998): $231-49$.

Manners, Lan, and Richard Whitman. "T be 'Difference Fingine': Constructing and Representing the International Ldentity of the European Union." Joumal of Enropean Puhlic Policy 10, no. 3 (20123): 380-404.

Mattern, Janice Bially. "Why 'Saft Power' Isr't So Saft: Representational Force and Attraction in World Politics." In Power in Warld Politis edited by Felix Berenskoetter and Michael J. Williams, 98-119. London: Routkdge, 2007.

Messetink, Annelies and Jan D. ten Thije. "Unity in Super-diversity- Iiuropean capacity and Intercultural Inquisitiveness of the Erasmas generation 2.0." Datch Journal of Applied linguistic 1, no: 1 (2012): $80-101$.

Michalski, Anna, "The EU as a Soft Power: the Foree of Persuzsion." In The New Public Diplomary, edited by Jan Melissen, 124-42. Basingstoke: Palgrave, 2005.

Noya, Javier, "The United States and Eurupe: Convergence or Diverpence in Public Diplomacy?" In The Present and Fuare of Public Diplomacy: A Eunopean Prospentive, the 2006 Madrid Confenerce on Public Diplomacy, edited by Javier Noya, 1-6. Madrid: Real Instituto Filcano, 2006, 
Padare, Lucia, Andrew Williams and lan Manners. The Republic of Moldows:Time for a Nay FU Strafgy? Brussels: SWP-CPN Selected Contributions, no. 5, 1999.

Patten, Chris. "lingagement is Not Liberal Mush," New Perspectiver Quarienty 19, no. 2 $(2002)=36-8$.

Pew Revearch Center. "A Year After Iraq War: Misltust of America in Europe Ever Higher, Muslim Anger Persists," March 16, 2004. httpc//people-press.ong/reports/ display.phñ 3 ?ReportiD -206

Ramussen, Steffen Bay. "The Messager and Practices of the European Union"s Public Diplamacy." The Hague foumal of Diphmacy, 5 (2010): 263-87.

Ramakrishns, Kumar. Emencency Propuspandas. The Wioning of Malayan Heants and Minds 1948-1958. London: Routledge, 2001.

Rosamond, Ben. "Three Ways of Speaking Eurupe to the World: Markets, Peace, Cosmopolitan Duty and the EU's Normative Power." Riritish Joumal of Pobitics and Internationd Reletions 15 (2013): http://onlinelibraryswiley.com/ doi/10.1111/14G7-856X.12013/abstract.

Scott-Senith, Giles. "Mending the 'Unhinged Alliunce' in the 1970s. Transatlantic Relations, Public Diplamacy, and the Origins of the European Union Visitors Program." Diplomacy \& Staternaft 16, no. $4(2005)$ : 749-78.

Sheehan, Neil. A Rright Shiving Lie: John Pual Vann and America in Viekam. London: Pimlica, 1998.

Smith, Michael. "The European Union and a Changing Europe: Estabhahing the Boundaries of Order." Joumal of Common Market Studies 43, no. 1 (1996): 5-28.

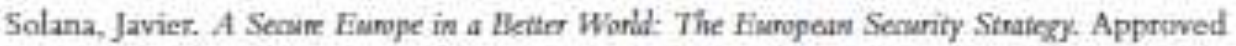
by the European Council held in Brussels an December 12,2003 and drafied under the responsibilities of the EU High Representative Javier Solana.

Sprenenburg. Dirk, and Raymond Puodevin. The History of the High Authority of the European Coul aud Steel Communiry: Supnuaztionatity in Openation. London: Weidenfeld \& Nicolsan, 1994.

Sturm, Paul, and Gigi Gya. "Shoring up the EU's Public Diplomacy in CSDP," Fiunopean Security Review, no, 52 (Novernber 2010). International Security Information Service, Europe,

Wallstrien, Margot, "Public Diplomacy and lts Role in the EU's Fixtermal Relations." Spech to the Mortan Center for International Studies, Georgetown University. Washington DC, SPEECH/08/494, October 2, 2008.

Whituan, Richard, Fowm Civilian Pouer to Superpower? The Intemational Identity of the Funspaan Union. Basingstoke: Macmillan, 1998.

Whitanan, Richard. ed. Normatise Power Europe: Eimporicd and Theoretical Perspectiver. Hasingstoke: Palgrave, 2011.

Whitman, Richand. "Europe Has to Berome a Change-Maker in Clobal Poditics," E?Sharp (July 4 2011): hitp//www.esharp,ea/Web-specials/Europe-hal-to-becomea-change-maker-in-gkbal-politics

Whitman, Richand, and Kalypso Nicolasidis, eds "European Union and Normative Power: Assessing the Decade." Coopenation and Couffict 47, no. 2 (2013): 167-329) special isue.

Wilson, lain. "What Should We Fixpect of "Erasmus Generations"?" Joumal of Common Manker Studies 49, no. 5 (2011). 1113-40.

Youngs, Richard. "Enygugement: Sharpening European Influence," In Cobbal Eumope: New Tenes of Engagenent edited by Richand Youngs, 1-14. London: Fnneign Policy Centre, 2005 . 